\title{
Reviewing the Unreviewable Judge: Federal Prosecution Appeals of Mid- Trial Evidentiary Rulings
}

\author{
Scott J. Shapiro
}

When a party to a suit lacks the right to appeal, the authority of the presiding judge to determine the litigant's fate is virtually absolute. By allowing the correction of injustices resulting from mistakes of law and heterodox interpretations of settled doctrine, the right to appellate review acts as a fetter to this enormous power of the nisi prius judge. It is therefore noteworthy that in Federal criminal cases any mid-trial evidentiary ruling that favors the defendant is forever insulated from review.

Under present Federal statutory law, the Government may only seek review from evidentiary rulings made before jeopardy has attached. ${ }^{1}$ As a result, any evidentiary ruling adverse to the prosecution made after the trial has begun is not appealable as an interlocutory ruling. The evidentiary matter can only be appealed after a final judgement, i.e., after the verdict. However, in the only instance when the Government cares to appeal the adverse ruling-when the defendant is acquitted-appeal is precluded by the double jeopardy clause. ${ }^{2}$ The Government is therefore faced with a situation in which mid-trial suppression and exclusion orders are never reviewable. This result can be disastrous for the prosecution if the suppression or exclusion was made erroneously and the acquittal was predicated on the fact that the jury never heard the inculpatory evidence.

The above scenario suggests that all evidentiary rulings must be made before trial. However, there may be good cause for suppressing evidence

\footnotetext{
1. The Govenment may take an appeal

from a decision or order of a district courts suppressing or excluding evidence . . . in a criminal proceeding, not made after the defendant has been put in jeopardy and before the verdict or finding on an indictment or information, if the United States attorney certifies to the district court that the appeal is not taken for the purpose of delay and that the evidence is a substantial proof of a fact material in the proceeding.
}

18 U.S.C. $\$ 3731$ (1988) (emphasis added). Jeopardy attaches during a jury trial when the jury is sworn, see Crist v. Brest, 437 U.S. 28, 37-38 (1978), and during a bench trial when the first witness is sworn, see Serfass v. United States, 420 U.S. 377,388 (1975).

2. See Kepner v. United States, 195 U.S. 100, 129-30 (1904); United States v. Ball, 163 U.S. 662, 671 (1896) (dictum). It should be noted that three out of the nine justices in Kepner disagreed with the rule prohibiting appeals following acquittals. Writing for the dissenters, Justice Holmes argued that a defendant can be put in jeopardy only once for each criminal cause of action and that a reversal oi an acquittal following appeal merely extended the original jeopardy into the second trial. See 195 U.S. at 134-37. 
in mid-trial, rather than beforehand. New evidence might be found after the trial begins, ${ }^{3}$ or the resolution of the suppression matter may not be separable from the determination of the defendant's guilt or innocence. ${ }^{4}$ In addition, there are numerous evidentiary issues of relevance, prejudice, and hearsay that clearly cannot be anticipated or resolved before the start of testimony at trial. One cannot ignore evidence merely because it must be evaluated after jeopardy attaches.

All the same, the Government's inability to appeal adverse rulings is cause for distress. Without any safety net in which to catch judicial error, society's interest in law enforcement is greatly compromised. The community incurs an incalculable expense when the vast machinery constructed to bring criminals to justice can be felled by the simple error of a single unreviewable judge.

Furthermore, the problem of the unreviewable judge is becoming increasingly significant in the Federal system. In an era when the energies of Government law enforcement agencies are focused on more complex crimes, the cost of unreviewable judgments increases. In the past ten years, the offices of the United States attorney have focused on a greater number of white-collar crimes. Criminal investigations of public corruption $^{\mathbf{b}}$ and fraud, ${ }^{6}$ for example, often employ many more human and financial resources than the more traditional violent and narcotics-related inquiries. As former United States Attorney Robert Fiske noted, "there has been a reluctance on the part of many investigators and prosecutors to get deeply involved in white-collar crime investigations because they are difficult, require far greater resources, and result in far fewer cases-fewer statistics-in proportion to the effort expended." The increased emphasis on these high profile investigations is thought to be justified by the belief that the deterrence value of conviction is great, and that the social and economic $\operatorname{costs}^{8}$ incurred by these crimes are devastatingly high. Given the

3. See FED. R. CRIM. P. 12(f) (motion to suppress must be made before trial unless cause exists for its deferral).

4. See FED. R. CRIM. P. 12(b)(3) (motion to dismiss may be entertained before trial only if determination of motion can be made without trial of general issue).

5. In 1975,53 indictments were issued charging offenses dealing with the abuse of public office. In 1985, 563 indictments were filed, an increase of 1062\%. U.S. DEP'T OF Justice, BurEau OF Justice Statistics, Sourcebook of Criminal Justice Statistics 371 (1985).

6 . For the same 10 year period, the increase in fraud cases filed in the federal district courts rose $180 \%$, from 3958 to 7109 . In 1985 , fraud cases amounted to $15 \%$ of all federal criminal prosecutions. Admin. OfFice of the U.S. Courts, Federal OfFENders IN the U.S. Courts 30, 48, X-1-33 (1985).

7. Fiske, Foreword, 18 Am. CRIM. L. REv. 165, 166 (1980).

8. The Joint Economic Committee of Congress estimated that the cost of white-collar crime in the United States during 1976 exceeded $\$ 44$ billion a year, as compared to the $\$ 4$ billion loss that is estimated to result from crimes against property. See STAFF of House COMM. ON THE JUdiciarY, 95th Cong., 2d Sess., White Collar Crime: The Problem and the Federal Response 10 \& n.20 (Comm. Print 1978). The $\$ 44$ billion figure does not represent the estimated $\$ 25$ billion a year lost due to fraud against government programs. See CoMptroller GEN. OF THE U.S. Gov'T, GEN. accounting Office, Federal Agencies Can, and Should, Do More to Combat Fraud in Government Programs 7 (1978). 
already limited number of white-collar investigations, the blow delivered by an erroneous and unreviewable ruling to the long-term strategic policies of law enforcement can be crippling.

The social cost resulting from the prosecution's inability to appeal may also express itself in a demoralizing effect on law enforcement agencies. Perhaps nothing is more frustrating to individuals in law enforcement than the nullification of their efforts by erroneous rulings. A large number of prosecutors, agents, and administrative staff may be involved for their entire public service career on a single case. A working environment in which their efforts are mobilized in vain may well foster cynicism. ${ }^{9}$

The Federal response to the problem of the unreviewable judge has taken two routes. One circuit court has laid down guidelines specifying which evidentiary issues must be decided before trial begins and which may be deferred. ${ }^{10}$ At least two district courts have attempted to solve the Government's dilemma by developing a procedural device that converts unappealable mid-trial rulings into appealable pre-trial ones through the grant of a mistrial."1 This Note will examine the efficacy and constitutionality of these solutions. It will be argued that although these attempts are not the most effective, they are helpful in pointing a way to a better solution. An optimal solution would not only allow the review of evidentiary rulings entered during trial, but also would protect the defendant against possible abuse by the prosecution. A survey of the historical development of Government appeals in the Federal system will be useful in placing the problem in context. Against this background, it will be seen that the proposed solution to the problem of the unreviewable judge is the natural extension of the legislative project concerning Government appeals in criminal cases.

\section{A Brief History of the Problem}

\section{A. The Common Law Rule and Its Discontents}

The history of the Government's right to appeal in criminal cases has been very kind to the unreviewable judge. The English Common Law rule prior to 1700 stated that neither the prosecution nor the defense had the right to appeal in criminal cases. A writ of error was granted only as a matter of grace from the Crown. ${ }^{12}$ Thereafter, the prosecution and defendant were permitted to seek review as of right when there was probable error, but no writ of error was to be had from a verdict of conviction. ${ }^{13}$

9. See Miller, Appeals by the State in Criminal Cases, 36 YALE L.J. 486, 512 (1927).

10. See infra text accompanying notes 38-42.

11. See infra text accompanying notes $43-50$.

12. Rex v. Wilkes, 4 Burr. 2527, 2550, 98 Eng. Rep. 327, 339-340 (1770).

13. See id.; J. Stephen, A General. View of the Common Law of England 171 (2d ed. 1890). 
The defendant had no right to challenge the fact-findings of the jury and the only recourse was to apply to the Crown through the Secretary of State for the Home Department for a pardon. ${ }^{14}$

In the Federal courts, ${ }^{15}$ defendants were given in 1891 the statutory right to apply for writs of error in most instances. ${ }^{16}$ However, the Government was granted no corresponding right. The Supreme Court held in United States v. Sanges ${ }^{\mathbf{1 7}}$ that, without legislative authority, the Government did not have the right to appeal in criminal cases. The Court reasoned that "the defendant, having been once put upon his trial and discharged by the court, is not to be again vexed for the same cause, unless the legislature, acting within its constitutional authority, has made express provision for a review of the judgment at the instance of the government." 18

Sanges was decided in 1892. The Court's holding in that case prompted the United States Attorney General to issue the first recommendation requesting that Congress grant the Government the right to appeal in criminal cases. Attorney General Miller's main concern was the unbridled power of the district judge: "As the law now stands, therefore, it is in the power of the single district judge. . . to defeat any criminal prosecution instituted by the Government, ... and there is no possible remedy or way to right the wrong." ${ }^{19}$ This plea was echoed by each successive Attorney General for the next fourteen years. ${ }^{20}$

Congress was alerted to this problem following the debacle of the 1906 Beef Trust Case. ${ }^{21}$ In this action, the defendant was charged with conspiring in restraint of trade and with an attempt to monopolize, in violation of sections 1 and 2 of the Sherman Act. After months of extensive investigation by the Department of Justice and a Federal grand jury, the district

14. See J. STEPHEN, supra note 13 , at 172 .

15. Among state jurisdictions, there existed little consensus on the issue of appealability in criminal cases. Compare Conn. Gen. Stat. § 1637 (1887) and State v. Lee, 65 Conn. 265, 265-69, 30 A. $1110,1110-13$ (1894) (prosecution permitted to appeal all matters of law arising from criminal action, even after acquittal, and double jeopardy did not bar retrial following reversal) with State v. McGrorty, 2 Minn. 224 (1858) (state not permitted to seek review of any matter of fact or law in criminal case, whether during or before trial, even though trial judge had certified point to higher court and defendant consented).

The Supreme Court initially held that the double jeopardy provision did not bind the states. See Palko v. Connecticut, 302 U.S. 319, 322 (1937). The Court later overruled this decision and held that the double jeopardy clause was to be incorporated into the Fourteenth Amendment. See Benton v. Maryland, 395 U.S. 784, 793-96 (1969).

16. In 1889 , defendants were permitted to appeal to the Supreme Court only in capital cases. Act of Feb. 6, 1889, ch. 113, § 6, 25 Stat. 656-57. This right was expanded in 1891, allowing defendants a writ of error in any case involving statutory construction or constitutional validity. Judiciary Act of 1891 , ch. $517, \S 5,26$ Stat. 826,828 .

17. 144 U.S. 310 (1892).

18. Id. at 318.

19. 1892 ATT'y GEN. ANN. REP. xxiv-Xxv.

20. See 1893 Att'y Gen. AnN. Rep. xxvi; 1899 Atr'y Gen. ANn. Rep. 33; 1900 AtT'y Gen. ANN. ReP. 40; 1903 AtT'y Gen. ANN. ReP. vi; 1905 ATT'y GEN. ANN. ReP. 10-11; 1906 AtT'y GEN. ANN. REP. 4-5.

21. United States v. Armour \& Co., 142 F. 808 (N.D. Ill. 1906). 
judge directed a verdict for the defendant at the close of the trial because he was of the opinion that the inculpatory evidence used by the prosecution violated the defendant's Fifth Amendment right against self-incrimination. ${ }^{22}$ The buck stopped at the district court-no appeal was available.

Government frustration was felt all the way at the top. During his annual message to Congress in 1907, Theodore Roosevelt expressed his disappointment with the existing state of appellate jurisdiction:

It seems an absurdity to permit a single district judge, against what may be the judgment of the immense majority of his or her colleagues on the bench, to declare a law solemnly enacted by the Congress to be "unconstitutional," and then to deny the Government the right to have the Supreme Court definitely decide the question. ${ }^{23}$

\section{B. The Development of the Statutory Scheme}

Roosevelt was not the only Federal offical concerned. The House of Representatives had already drafted a statute that allowed the Government the right to appeal in all cases, except where a judgment had been entered in favor of the defendant. ${ }^{24}$ When the bill reached the Senate, however, the Judiciary Committee substantially reworked it, allowing appeals in only very limited circumstances. ${ }^{25}$ That the bill even survived the floor debate was quite miraculous given the hostility that many Senators felt towards any government appeals. ${ }^{26}$

When the revised bill was sent back to the House, many Representatives were furious over the senatorial butchering it had suffered. Congressman Jenkins, one of the House bill's chief sponsors, bitterly quipped that he thought a criminal could not have done a better job drafting the statute. ${ }^{27} \mathrm{~A}$ secret conference between the House and Senate followed, during which the Senate bill was marginally revised to allow direct review to the Supreme Court-a concession to the House supporters. The new

22. Id. at 822 .

23. 41 CONG. REC. 22 (1906).

24. H.R. 15434, 59th Cong., 2d Sess., 40 Cong. Rec. 5408 (1906).

25. Appeals were provided only in the following instances: (1) from a decision quashing, setting aside, or sustaining a demurrer to an indictment; (2) from a decision arresting judgment of a conviction based on the insufficiency of the indictment; and (3) from a decision sustaining a special plea in bar when the defendant had not been placed in jeopardy. See S. REP. No. 3922, 59th Cong., 1st Sess. 1 (1906).

26. See, e.g., 41 Cong. Rec. 2191-92 (1907). The Senate eventually approved the Judiciary Committee's bill with the further limitations that (1) right to review be restricted to questions of statutory construction and constitutional invalidity; and (2) the provision for direct review to the Supreme Court be eliminated. Id. at 2825.

27. Id. at 3044 . 
bill passed in both houses of Congress soon after the meeting, ${ }^{28}$ and was signed into law as the Criminal Appeals Act of 1907.29

As one would expect, the Criminal Appeals Act had little effect on the unreviewable judge. The Government still had no right to appeal an adverse evidentiary matter made either before or during trial. In addition, if the ruling was made after jeopardy attached, the decision of a district court judge to quash an indictment based on its unconstitutionality or statutory construction was also insulated from appeal. ${ }^{30}$

It took Congress another 60 years to act decisively. ${ }^{31}$ In 1968, as part of the Omnibus Crime Control and Safe Streets Act, ${ }^{32} 18$ U.S.C. § 3731 was finally amended to allow the Government to appeal pre-trial evidentiary suppression orders. Mid-trial evidentiary appeals, though, were expressly denied. ${ }^{33}$ This expansion of the Government's rights was intended to combat the broad grant of protection afforded the defendant by the Warren Court in the years preceding. Many politicians felt that the liberal Federal district courts had lost their sense of proportion with regard to the suppression of evidence and that their excesses might be curbed by allowing the prosecution to seek appellate review. ${ }^{34}$ The trend continued

28. Id. at 3994,4128 .

29. The Criminal Appeals Act of 1907, ch. 2564, 34 Stat. 1246 (1907) (codified as amended at 18 U.S.C. $\$ 3731$ (1988)).

30. A telling illustration of the ineffectiveness of the Criminal Appeals Act in dealing with judicial unreviewability is the dilemma the Supreme Court faced in United States v. Weissman, 266 U.S. 377 (1924). In Weissman, the district court had quashed the indictment immediately after the jury was impaneled, even before opening statements were delivered. The district court then directed a verdict for the defendant. Id. at 378. The Government appealed, claiming that the trial judge intentionally manipulated the procedure by waiting to quash only after the defendant was placed in jeopardy, in order to insulate the interlocutory ruling from appellate review. Speaking for the Court, Justice Holmes recognized that the actions of the judge were suspect but nevertheless held that "such considerations do not affect the construction of the act." Id. at 379. The legal insufficiency of the indictment could not be tested on review. Thus, while the Court recognized that the district judge should not have done what he did, the Court also affirmed that he could do what he did.

31. Congress had half-heartedly addressed the problem in the past, but its efforts met with little success. In 1942, the Criminal Appeals Act was amended, Act of May 9, 1942, ch. 295, 56 Stat. 271, to allow appeals from decisions quashing indictments or arresting judgments where the basis of the ruling was other than statutory construction or constitutional validity. Like its 1907 progenitor, the 1942 amendment did little to alter the unreviewable status of judicial rulings. As before, any decision issued after the jury was impaneled was unreviewable. With regard to pre-trial evidentiary rulings, the situation was improved somewhat. A pre-trial suppression order was appealable if the district court characterized its order as a dismissal based on illegal evidence. See United States v. Ashby, 245 F.2d 684, 685 (5th Gir. 1957). However, if the trial judge labeled his ruling as a dismissal based on insufficient evidence, then appeal was not covered by the amendment to 18 U.S.C. $\$ 3731$. See United States v. Janitz, 161 F.2d 19, 21 (3d Gir. 1947). The mistaken judge would thus escape scrutiny if he happened to characterize the dismissal in a certain way.

32. Pub. L. No. 90-351, § 1301, 82 Stat. 237 (1968).

33. This opened up the possibility that the defendant could defeat the government's right to appeal by saving an evidentiary objection until jeopardy attached. Such delays, though, were generally treated as untimely. See United States v. Rollins, 522 F.2d 160, 165 (2d Cir. 1975); United States v. Barber, 495 F.2d 327, 329 (9th Gir. 1974); see also 1968 U.S. CoDE CoNG. \& ADMIN. NEws 2195 ("Care must be exercised to avoid having a defendant defeat the right of appeal . . . by waiting until trial."). This loophole was formally closed in 1975 when Rule 12 of the Federal Rules of Criminal Procedure was amended to provide that failure to move for a suppression motion before trial without just cause is to be considered a waiver of the right to object. See FED. R. CRIM. P. 12(c), (f).

34. Consider the statement of Representative Poff during the bill's debate: 
and, two years later, Congress granted the Government the right to appeal dismissals in all cases not barred by the double jeopardy clause. ${ }^{35}$

As we have seen, the expansion of the Government's right to appeal in criminal cases historically has been motivated by the desire to constrain the power of the district judge. Why then did Congress stop just short of granting mid-trial interlocutory appeals? According to one court, "the only evident purpose in establishing the limited exception as to orders entered during trial was to prevent the suspension or interruption of ongoing trials." ${ }^{36}$ Such a policy is obviously sound-one could not expect the jury's (or, for that matter, the trial judge's) memory to remain fresh while opposing counsel prepared briefs and argued before a court of appeals. Appeals pursued in the middle of a criminal trial are unacceptable because they destroy the trial's delicate continuity.

\section{The Solutions}

The availability of pre-trial appeals under section 3731 indicates that the need to fetter the district court can often be harmonized with the need to preserve trial continuity. When both policies can be accommodated, the Government's right to appeal ought to be protected. One can thus imagine two situations where the Government should have recourse when faced with potentially unappealable mid-trial orders. First, the prosecution might appeal the district court's decision to postpone the evidentiary decision until the trial rather than ruling before trial. Second, one could develop some means of converting mid-trial orders into pre-trial ones through a grant of a mistrial. We shall see that the above suggestions not only reflect sound policy but also enjoy support in Federal case law.

At the present time, the prosecution of many significant cases in the Federal courts is thwarted because of the holding of a single district judge that a confession or admission has been unlawfully obtained or that the identification of a defendant by his victim or by an eyewitness to the crime was unlawful. By authorizing an appeal in such cases, and thereby allowing an appellate court to determine whether the decision of the district judge suppressing the evidence is in accord with the existing law, title VIII may enable many of these prosecutions to be saved.

114 Cong. REC. 16278-79 (1968).

35. Ominbus Crime Control Act of 1970 (Criminal Appeals Act), Pub. L. No. 91-644, §14(a), 84 Stat 1881, 1890 (1971). Roughly, appeals are constitutionally invalid when the dismissals are based on the trial judge's determination that the defendant is not guilty based on the factual merits of the case. If the dismissal is based on a legal theory, i.e., a judgment that no criminal violation had occurred even if the facts set out in the indictment were true, then that order is appealable, regardless of when the ruling by the trial judge was made. This Note will not deal with dismissals because those situations do not raise unreviewability problems. An erroneous ruling on a matter of law which results in a dismissal will be appealable. See Note, Government Appeals of "Dismissals" in Criminal Cases, 87 Harv. L. REv. 1822, 1837-41 (1977).

36. United States v. Beck, 483 F.2d 203, 205 (3rd Cir. 1973) (interpreting vague legislative intent set out in S. REP. No. 1296, 91 st Cong., 1st Sess. 13 (1969)). 


\section{A. Forcing the Pre-Trial Ruling}

The Government is usually permitted to secure an evidentiary ruling before trial. ${ }^{37}$ However, for obvious reasons, the Government cannot demand one as a matter of right. Evidentiary matters are by their very nature holistic. Questions of admissibility are usually predicated on a background of interwoven fact patterns, and the facts set out in the record, either in the indictment or affidavits accompanying the motion, are often insufficient to permit an informed decision. To rule on issues of illegality, the trial judge may need to hear from Government officials concerning the particulars of their past investigations and the determination of prejudice may necessitate that the judge acquire a "feel" for the case. To hold a mini-trial in order to decide an evidentiary matter may cause great delay for the defendant and contribute to court inefficiency.

Nevertheless, if the Government's right to appeal is worth protecting, deferral decisions cannot be left solely in the discretion of the trial court. The need for such a guiding rule was first perceived by the First Circuit in United States $v$. Barletta. ${ }^{38}$ In Barletta, the defendant requested an evidentiary ruling on the admissibility of certain taped conversations between himself and a Government informant. With the consent of the two parties, the trial judge waited until the trial began and then ruled to exclude the tapes, basing the decision on their prejudicial nature and lack of probative value. After a mistrial was declared due to a hung jury, the Government sought a pre-trial reconsideration of the exclusion ruling. The district court denied the motion on the ground that an informed decision had to await retrial.99

The Government appealed the district court's deferral, claiming that the court had no good reason for awaiting trial and that without a pretrial ruling, an appeal on the merits would be unavailable pursuant to 18 U.S.C. § 3731. The First Circuit agreed and set forth the following rule: "[A] district court must rule on any issue entirely segregable from the evidence to be presented at trial, but may in its discretion defer a ruling on any motion that requires trial of any non-trivial part of the 'general issue'. . . " 40 The court accordingly distinguished three types of evidentiary motions based on the degree of probative complexity. The first class consists of questions that would require a virtual mini-trial for their determination, such as the admissibility of co-conspirator hearsay. The motions in this class must be deferred. The second class involves issues that overlap with evidence relating to the general issue to be presented at trial. In such cases, it is in the district court's discretion whether or not to defer.

37. See United States v. Abraham, 541 F.2d 624, 626 (6th Cir. 1976) (district court may entertain motion to suppress at Government's request).

38. 644 F.2d 50 (1st Cir. 1981).

39. United States v. Barletta, 492 F. Supp. 910, 912-14 (D. Mass. 1980).

40. 644 F.2d at $57-58$. 
The third class is made up of motions that can be decided with little or no presentation of the evidence pertaining to the general issue. Situations requiring such de minimis review must be decided before trial.1 The Barletta court held that the motion under review fell into the third category. Since a trial had already occurred and the district court had heard all the relevant evidence, no additional evidence needed to be presented before trial in order to decide the motion. The court found the deferral motion improper and reversed the district court, instructing it to rule on the evidentiary matter before the trial began. ${ }^{42}$

The Barletta ruling holds great significance for the issue of judicial unreviewability. It is here that one may first discern the willingness of an appellate court to protect the Government's need to appeal against the district court's normally overriding power. The Barletta holding constrains the trial judge from deferring evidentiary rulings that can efficiently be addressed before trial. Further, it endows the court of appeals with corrective authority to reverse such judicial errors.

However, the advances won by the Barletta rule may in fact be more theoretical than practical. As mentioned above, evidentiary issues often resist de minimis consideration. To be sure, there will be a wide range of matters that cannot be handled as easily before trial as were the issues in Barletta. In Barletta, the evidence had already been introduced during the previous trial. There was thus no need for a pre-trial evidentiary hearing. In addition, even if the prosecution could receive all the pre-trial rulings it wanted, this right would be of little use in situations where evidence was uncovered after trial began. By itself, the Barletta rule cannot be the exclusive remedy for the prosecutor facing the unreviewable judge. A more comprehensive solution is required.

\section{B. Mid-trial Rulings and the Possibility of Appeal}

It is particularly interesting to see how unreviewable judges who wish to be reviewable have dealt with the Government's predicament. If a trial judge wishes to preserve the Government's right to appeal but must wait to rule until the middle of trial, he has two alternatives. The first choice is to strike a bargain with the defendant. The judge will consider the motion only if the defendant waives his double jeopardy rights with regard to the evidentiary matter. This approach was used by the district court in United States $v$. Kington..$^{43}$ In Kington, the defendant moved for a pre-trial suppression hearing, but the judge decided the motion only after the jury was empaneled. Without the Government's prompting, the trial judge proposed the following compromise: If the defendant agreed to waive his

41. Id. at 58.

42. Id. at 59-60.

43. 801 F.2d 733 (5th Cir. 1986). 
double jeopardy rights, the jury would be discharged in order for the Government to seek an appeal, and, following appeal, former jeopardy would not bar retrial. If the defendant refused, the motion would not be considered. The defendant chose to waive his double jeopardy rights. Accordingly, the jury was discharged, and upon appeal the court of appeals reversed the district court's evidentiary ruling. The defendant then challenged the district court's compromise, claiming that former jeopardy barred retrial.

The Fifth Circuit held the reprosecution and appeal to be proper. It reasoned that former jeopardy did not act as a bar because the defendant had explicitly waived his double jeopardy rights at trial. ${ }^{44}$ It further held that the appeal did not violate the congressional sanction against mid-trial appeals because the appeal itself did not interrupt the ongoing trial. Rather, the trial terminated because the district court ruled that a mistrial was required and thus the post-trial appeal did not run afoul of section $3731 .{ }^{45}$

The second possibility is for the trial judge to declare a mistrial and rule on the evidentiary issue before retrial so that the Government can petition for an appeal. This approach was validated by the Fifth Circuit in United States v. Moon. ${ }^{48}$ In Moon, the defendant moved for a ruling on an evidentiary matter after the jury was sworn in, whereupon the trial judge suppressed a large portion of the Government's evidence. The trial judge granted the Government's motion for a mistrial but cautioned the Government that subsequent prosecution might be barred by former jeopardy ${ }^{47}$ Upon reindictment, the district court ruled that former jeopardy barred retrial. ${ }^{18}$ The Government appealed and the Fifth Circuit reversed the dismissal, claiming that the trial judge's consideration of defendant's evidentiary motion after jeopardy had attached wrongly denied the Government its right to appeal. ${ }^{40}$ The mistrial was therefore proper and did not bar reprosecution. ${ }^{.0}$

\section{The Proposed Solution}

The cases set out above demonstrate that there are ways for a district court to protect the Government's interest in securing an appeal on evi-

\footnotetext{
44. Id. at 735 .

45. Id. at $735-36$.

46. 491 F.2d 1047 (5th Cir. 1974).

47. Id. at 1049 .

48. Id.

49. Id. at 1049-50.

50. The district court's approach in Moon is similar to that taken by Illinois state courts when dealing with interlocutory appeals brought by the prosecution during trial. If the defendant has good cause to raise an evidentiary matter after he has been put in jeopardy, the judge must grant a mistrial if the state requests one. If the trial court does not grant a mistrial, the appeals court will direct the trial court to do so on review. See ILL. ANN. STAT. ch. 38, para. 114-12(c) (Smith-Hurd 1977 \& Supp. 1988); People v. Hoban, 57 Ill. App. 3d 25, 27-28, 372 N.E.2d 976, 977 (1978).
} 
dentiary matters decided during trial. However, a district judge who does not choose to accommodate the Government creates great difficulties for the prosecution. A possible solution would be to require the district court to present the defendant with an ultimatum whenever it appears that the Government will not be able to appeal an adverse ruling. If the court determines that good cause exists to entertain the defendant's evidentiary motion during trial, the Government would have the right to make the defendant either choose a mistrial and waiver of his double jeopardy rights or allow the court to rule in the Government's favor.

In this way, the Government can protect itself from the dangers of unreviewable orders. For if the defendant chooses the mistrial option, the prosecution could appeal the ruling as a pre-retrial interlocutory appeal under section 3731, and retrial would not be barred. Alternatively, if the defendant were content to continue the trial with his motion denied, the prosecution would have no reason to seek appeal. The failure of the district court to make the defendant choose would itself be an appealable issue, subject to reversal and remand by the court of appeals.

Such a motion would be structurally different from the procedural devices used by the district courts in Kington and Moon. Unlike the Kington compromise where power resided solely with the trial judge, the Government would have the right to demand that the defendant choose. The proposed motion also would differ from the Moon order by allowing the defendant to elect a mistrial rather than forcing it upon him.

In addition, the above motion would be supplemented with two substantive restrictions. First, only the suppression of material evidence would be reviewed. By requiring that the district court make a finding of materiality, the proposal would ensure that not every evidentiary ruling will be sufficient to force the defendant to make this difficult choice. Second, just as section 3731 requires a certification regarding pre-trial appeals, it would also be necessary that the United States attorney for the district review the case and certify that the proposed motion is not designed to cause delay or to gain an unfair advantage. ${ }^{51}$ As will be shown, the motion described above is a significant improvement over the Kington and Moon prototypes in protecting the defendant against prosecutorial abuse. $^{\mathbf{6}}$

\section{Doubts Concerning the Proposed Solution}

Since section 3731 does not permit appeals after jeopardy attaches, the proposal seeks to maximize the Government's right to appeal pre-trial rulings. The proposal is consistent with the congressional grant of appel-

51. One might also require that such appeals be given priority on the appellate docket. See, e.g., Haw. Rev. Stat. § 641-13(7), (8) (1988).

52. See infra text accompanying notes $74-76 \&$ note 76 . 
late rights for it does not sanction mid-trial review but only the review of mid-trial orders that, in a more perfect world, would have been made before trial began. However, the proposal may appear to be a subtle circumvention of congressional authority. Courts have often been wary of judicial expansion of the Government's right to appeal in criminal cases, ${ }^{53}$ and simply because a procedure is consistent with an existing statute does not indicate that it has legislative approval. Furthermore, the question concerning judicial authority is moot if the forced election of the defendant is found to be constitutionally invalid. In this respect, it is far from obvious that the above proposal is consistent with the double jeopardy clause since the defendant may be forced to waive his rights to refuse reprosecution.

Fortunately, one issue bleeds into the other for, as we will see, former jeopardy does not bar reprosecution following certain types of mistrials because trial courts are under a duty to declare them..$^{54}$ If the problem of the unreviewable judge falls under the mistrial exception to the double jeopardy clause, it does so because it is a problem that, like many others, trial courts are charged with solving. Thus, when the proposal is viewed not as surreptitiously expanding the Government's substantive rights to appeal but rather as isolating an instance of required mistrial, it will be apparent that the proposal is not only constitutional but also fit for judicial creation.

\section{The Constitutionality of the Solution}

\section{A. An Objection to the Solution}

A constitutional objection that the above proposal violates the double jeopardy clause should not be understood as attacking the proposal for explicitly eliminating the defendant's rights not to be tried twice. This objection would not be well-founded, because the defendant is given a choice between a mistrial and foregoing the evidentiary victory. Rather, one could reasonably complain that the choice functionally reduces the double jeopardy guarantee to a hollow entitlement. A choice between preserving one's right to complete the first trial and another right to suppress evidence that ought to be suppressed is a choice between two unsatisfactory options. The worth of either of the disjunctive rights has thus been significantly diminished.

The reply to this challenge cannot be answered before analyzing the policies underlying the double jeopardy provision. Whether the proposed solution to the unreviewable judge is unconstitutional will depend on whether the rationale behind double jeopardy is found to be compromised.

53. See Arizona v. Manypenny, 451 U.S. 232, 245-46 (1981); Carroll v. United States, 354 U.S. 394, 400 (1957); United States v. Sanges, 144 U.S. 310, 318 (1892).

54. See infra text accompanying notes 68-73. 


\section{B. Rationale Behind the Double Jeopardy Protection}

The Fifth Amendment of the Constitution provides that no person shall "be subject for the same offence to be put twice in jeopardy of life or limb." ${ }^{\text {"Bs }}$ In Green v. United States, ${ }^{\text {s6 }}$ the Court neatly summarized the policies underlying this Fifth Amendment provision:

The underlying idea, one that is deeply ingrained in at least the Anglo-American system of jurisprudence, is that the State with all its resources and power should not make repeated attempts to convict an individual for an alleged offense, thereby [1] subjecting him to embarrassment, expense and ordeal and [2] compelling him to live in a constant state of anxiety and insecurity as well as [3] enhancing the possibility that even though innocent he may be found guilty. ${ }^{57}$

The first justification behind the double jeopardy provision is that placing a presumptively innocent person on trial causes that person great embarrassment and expense. If the Government, which has vastly greater resources than the average defendant, is allowed to prosecute the defendant repeatedly even after an acquittal, the defendant will be unfairly harassed and worn down emotionally and financially. Therefore, the Government should be allowed only one chance at each conviction.

The second policy announced in Green is closely related to the first: Once a trial has begun in which the defendant's future is uncertain, the defendant has a strong interest in seeing that his case is settled conclusively. To endure both the trauma of a trial and the risk of reversal of a favorable verdict on appeal is too emotionally taxing for a defendant to bear. ${ }^{58}$

While the policies of limiting harassment and uncertainty are certainly noble, they play a limited role in the mechanics of the double jeopardy protection. Retrial is permitted in many instances, even though the defendant is subject to great harassment and anxiety. It has long been recognized that retrial following a mistrial is proper when there exists a "manifest necessity"58 for the declaration of a mistrial and the aims of public justice will thus be served. In the classic example of manifest necessity, a mistrial resulting from a hung jury is retriable. ${ }^{.0}$ Reprosecution is also permitted after a reversal of a conviction on appeal. ${ }^{61}$ In other cases, a

55. U.S. Const. amend. V. For an excellent discussion of the history of the double jeopardy protection throughout the ages, see generally J. Sigler, Double JeOPARDY (1969).

56. 355 U.S. 184 (1957).

57. Id. at $187-88$.

58. This policy is often described in terms of "the defendant's valued right to have his trial completed by a particular tribunal." Wade v. Hunter, 336 U.S. 684, 689 (1949).

59. See United States v. Perez, 22 U.S. (9 Wheat.) 579 (1824).

60. Id. at 580 .

61. See United States v. Ball, 163 U.S. 662, 672 (1896); cf. Burks v. United States, 437 U.S. 1, 15-17 (1978) (limiting Ball rule to reversals not based on insufficiency of evidence at trial). 
second trial is considered proper after a jury acquittal when the first trial occurred in a court without jurisdiction. ${ }^{62}$ The dual sovereignty doctrine allows a Federal prosecution after a state acquittal for the same offense (and vice versa). ${ }^{63}$

These examples of reprosecution following a first trial demonstrate that the public's interest in the fair administration of the criminal process often outweighs the defendant's interest in limiting his personal expense and uncertainty. The above two considerations act as a bar to a second trial when the public good served by terminating the first trial is minimal. Therefore, mistrials are improper when the prosecution believes that the jury may not convict, or when it uses the first trial as a dry run in order to rehearse its case. ${ }^{64}$ Prosecutorial conduct designed to oppress the accused will likewise bar retrial. ${ }^{65}$ It is because a criminal trial is a lifealtering event for the defendant that the law demands adequate justification for a second go-around.

The third policy underlying double jeopardy protection reflects the different concern that a second fact-finding increases the probability of an unjust conviction. That the exposure to this risk is considered so unjustified by Federal courts is evidenced by the doctrine that an acquittal will stand even in the face of an egregiously erroneous ruling by the trial judge. ${ }^{68}$ This policy, by its very nature, is only applicable when a factfinding has taken place. An acquittal, which is a fact-finding relating to the general issue of guilt or innocence, is therefore never appealable. Similarly, the third policy will bar appeals of dismissals when the insufficiency of an indictment is predicated on a fact-finding going to the defendant's culpability. Mistrials, on the other hand, do not result in any fact-finding; they are trials that are aborted in the middle. Retrying a defendant following a mistrial thus does not increase the risk of unjust conviction. ${ }^{87}$

\section{G. Manifest Necessity and the Unreviewability of Judges}

Since the proposed solution employs the grant of a mistrial to preserve the Government's right to appeal, retrial will be proper only if the societal interest outweighs the defendant's interest. The test of manifest necessity

62. See Ball, 163 U.S. at 669 (dictum); Johnsen v. United States, 41 F.2d 44, 46 (9th Cir. 1930), cert. denied, 282 U.S. 864 (1930).

63. See Abbate v. United States, 359 U.S. 187, 195 (1959); Bartkus v. Illinois, 359 U.S. 121, 137 (1959).

64. See Arizona v. Washington, 434 U.S. 497, 508 (1978).

65. See Oregon v. Kennedy, 456 U.S. 667, 675-76 (1982).

66. See Fong Foo v. United States, 369 U.S. 141, 143 (1962) (double jeopardy bars appeal even though district court directed verdict for defendant before Government concluded its case-in-chief).

67. It has been argued that the real policy behind double jeopardy is the preservation of the jury's prerogative to acquit against the weight of the evidence. See Westen, The Three Faces of Double Jeopardy: Reflections on Government Appeals of Criminal Sentences, 78 MICH. L. REv. 1001, 1021-23 (1980). Since this policy is applicable only in situations where there has been a fact-finding, it also does not apply to mistrial cases. 
is designed to set this limit. As Justice Story, the originator of this doctrine, explained in connection with hung juries,

[T]he law has invested Courts of justice with the authority to discharge any jury from giving a verdict, whenever, in their opinion, taking all the circumstances into consideration, there is a manifest necessity for the act, or the ends of public justice would otherwise be defeated. Courts are to exercise sound discretion on the subject; and it is impossible to define all the circumstances, which would render it proper to interfere. . . . But, after all, they have the right to order the discharge; and the security which the public have for the faithful, sound, and conscientious exercise of this discretion, rests, in this, as in other cases, upon the responsibility of the Judges, under their oath of office. ${ }^{\text {s8 }}$

This standard has also justified mistrials based on jury bias, ${ }^{69}$ defective indictments, ${ }^{70}$ trial judge illness, ${ }^{71}$ "acts of God" such as war, ${ }^{72}$ and defense counsel misbehavior which prejudices the prosecution's case. ${ }^{73}$

But the manifest necessity test does not only define the boundaries of double jeopardy. It also imposes an affirmative duty on the district courts to discharge a jury when the aims of public justice require it. The trial judge must ensure that the accused is tried in a fair proceeding which is designed to end in a just judgement. When the integrity of the trial is compromised and uncorrectable, the district judge should declare a mistrial.

It has been argued throughout this Note that protecting the Government's right to appeal damaging adverse rulings is also necessary to preserve the integrity of the criminal process. Without a method for trapping error, society is cheated out of a just trial. The functional similarity between defense counsel misconduct that damages the prosecutor's case and a judge's erroneous ruling that excludes the Government's chief evidence is too close to be ignored. In both instances termination of the first trial furthers the societal interest of justice.

The district court is therefore obligated to do something in order to solve this problem. But the answer cannot lie in the declaration of a mistrial whenever the defendant objects to Government evidence during trial. The reason is that not all evidentiary rulings need to be appealed-only important and potentially erroneous ones require review. Preserving the Government's right to appeal cannot always be a claim of manifest neces-

68. United States v. Perez, 22 U.S. ( 9 Wheat.) 579, 580 (1824).

69. See Thompson v. United States, 155 U.S. 271, 274 (1894); Simmons v. United States, 142 U.S. 148, 154 (1893).

70. See Illinois v. Somerville, 410 U.S. 458, 468-69 (1973).

71. See Freeman v. United States, 237 F. 815, 815 (2d Cir. 1916).

72. See Wade v. Hunter, 336 U.S. 684, 691-92 (1949).

73. See Arizona v. Washington, 434 U.S. 497, 513 (1978). 
sity, because the matter may not be important enough to appeal. How are we to know which evidentiary rulings are important to appeal and which are not? Clearly the prosecution cannot be assumed to be a fair judge as to the worth of the appeal. In contrast to the defendant, the prosecution may have little to lose by requesting a mistrial. Alternatively, the prosecution may wish to be released from the first trial because it believes that it has performed poorly and desires a second chance. The trial judge is also a poor guide, because she is the one that is ruling in favor of one of the parties. It would be beyond the scope of her powers to ask a judge to evaluate the fallibility of her own decisions.

The solution is to let the defendant decide the importance of appeal by having him choose whether to acquiesce to a mistrial. If the defendant believes that his evidentiary position has little merit, he will probably not opt for a mistrial. For if his contention is frivolous, the evidentiary ruling will be reversed on appeal and he will have to suffer through another trial with nothing gained. Or he may believe that the inculpatory evidence ought to be suppressed and therefore will opt for a mistrial-for if he decides to go forward with the trial and is convicted, his conviction might be overturned on appeal and he will be retried anyway. Since the decision is made by the interested party, the only matters that will be appealed through the grant of a mistrial will be those about which there exists serious disagreement.

Efficiency is not the only virtue of the defendant's deliberation and choice. Since it is the defendant who might be retried it is only fair that he should choose whether to incur this additional expense or continue with a somewhat injured trial position. The double jeopardy provision is meant to minimize the harassment of the defendant and its ends are best served by allowing the defendant to decide how much harassment he is willing to endure. Forced election, then, seeks to enhance the defendant's autonomy in connection with major trial decisions.

The solution proposed in this Note partly restores parity between the prosecution and defendant by using a variant of the "I cut, you choose" game strategy. ${ }^{74}$ Allowing the prosecution to make the initial motion not only creates the possibility of appeal but also ensures that the defendant cannot use the solution to escape from a bad trial position. Permitting the defendant the final choice guarantees that the prosecution's mistrial attempt will not be frivolous or deviously strategic. Since each party is given control over the grant of mistrial, no party can abort the trial unilaterally. This procedural fairness also achieves the socially desirable outcome: the

74. The "I cut, you choose" strategy is also known as the egalitarian solution for two-person zerosum games. See R. Luce \& H. RAIFfa, Games and Decisions 363-68 (1957). The classic example of the use of such a strategy is the situation in which two people wish to divide a pie equally. In order to ensure fairness, one person should cut the pie and the other one should choose the portion he desires. 
evidentiary issues that will be appealed are those that, in the eyes of both parties, would be colorable to an appellate court.

While such a strategy can successfully eliminate unnecessary mistrials, it cannot act as a complete safeguard against prosecutorial misconduct. Despite the defendant's ability to defeat any mistrial attempt, she does so at the price of losing the evidentiary ruling at the trial level. By using the threat of mistrial as a bargaining chip, the Government can prevail on any evidentiary issue that is not significant enough to trigger the defendant's mistrial consent but nonetheless it considers relevant to the factfinding.

The proposed solution is supplemented with materiality and certification requirements in order to preclude this strategic possibility. By making the motion conditional on the materiality of the evidence ${ }^{75}$ and the United States attorney's certification against delay, we ensure that a defendant is not penalized for reasonably wanting to avoid a mistrial for less than the most "weighty" of issues. The court can therefore supervise that a technique set up to establish parity is not itself used as an instrument of abuse. ${ }^{78}$

This Note has argued that the existence of the unreviewable judge should be sufficient to impose a duty upon the district court to require the defendant to choose between a mistrial or continuing the trial without the evidence suppressed. The societal interest in preserving the Government's right to appeal raises a presumption of manifest necessity which the defendant may rebut by choosing to forgo a mistrial. However, the reader may still not be convinced that the need for Government appeals is enough to justify such a conclusion. In reply to the skeptic it can be shown that if other considerations that are of less merit are enough to force the

75. The materiality condition is taken from the $\S 3731$ pre-trial provision requiring that the United States attorney certify that the evidence sought to be admitted "is a substantial proof of a fact material in the proceeding." Unfortunately, courts have not ruled on what consists of substantial proof of a material fact, chiefly because the function of the certification in a pre-trial appeal is merely to symbolize the prosecutor's good faith. Since in a mid-trial context the potential for abuse is much higher, proclamations of good faith are inadequate safeguards. Given that the trial court must decide what evidentiary issues will be sent up on appeal, it would seem that the only evidence that ought to be reviewed is the evidence that, if admitted incorrectly during the trial, would be grounds for reversal. Thus, the materiality standard for mid-trial appeals would follow the harmless error rule. See generally Chapman v. California 386 U.S. 18, 21-24 (1967) (harmless error in constitutional context); Kotteakos v. United States, 328 U.S. 750, 765 (1946) (harmless error in non-constitutional context).

76. There does exist one other possible scenario where the proposed solution can be used as a weapon against the defendant. In order to get a mistrial, the Government may choose to secrete substantial inculpatory evidence and claim to have discovered such evidence if it finds that the trial is going poorly. However, such instances will be quite rare. Given the fact that certification is required, a prosecutor will be most hesitant to defraud a Federal district court. In addition, only the most foolish of Federal district judges would accept a prosecutor's word that substantial evidence has been found after trial has begun and still believe that the prosecutor was willing to go to trial without the evidence in the first place. Fortuitous circumstances that allow a party to secure a mistrial when they desperately need it would clearly be suspect. 
accused to choose a mistrial, then a fortiori the unreviewability of judges should also be sufficient to justify a similar election.

\section{Mistrials at the Request of the Defendant and the Forced Election}

There are two varieties of mistrials. Mistrials based on manifest necessity are those granted by the district court over the objection of the defendant. In such a situation, the defendant does not want to end the first trial but the trial judge determines that justice requires that it be terminated. However, when the defendant moves for a mistrial, there is no requirement of manifest necessity because the defendant himself has struck the double jeopardy balance for the court. The defendant elects to submit to the harassment of a second trial because he believes that to continue with the first trial would do more harm than good. ${ }^{77}$

In order to best illustrate the constitutional logic of defendant-motivated mistrials, it is helpful to consider the Supreme Court's holding in United States $v$. Dinitz. ${ }^{78}$ The trial judge in Dinitz dismissed the defense counsel due to his incorrigible behavior during trial. The judge then presented the defendant with the following choices: to stay the trial pending appeal of the dismissal, to obtain a continuance to find new counsel, or to request a mistrial. The defendant opted for the third alternative. Subsequent to the grant of the mistrial, the defendant sought a dismissal of the new indictment, pleading former jeopardy. The district court granted the dismissal and the court of appeals affirmed. ${ }^{79}$ The appeals court reasoned that the defendant's request for mistrial did not act as a waiver of his double jeopardy rights because the three alternatives presented to him had been unsatisfactory. The defendant did not want to continue with the prejudicial atmosphere of the trial nor did he want to submit to a second trial. ${ }^{80} \mathrm{~A}$ waiver of a constitutional right must be voluntary, ${ }^{81}$ and the existence of this "Hobson's Choice" effectively eliminated the element of voluntariness from the defendant's selection.

The Supreme Court explicitly rejected the waiver theory of the court of appeals. As the Court explained:

[I]t is evident that when judicial or prosecutorial error seriously prejudices a defendant, he may have little interest in completing the trial and obtaining a verdict from the first jury. The defendant may reasonably conclude that a continuation of the tainted proceeding would result in a conviction followed by a lengthy appeal and, if a reversal is secured, by a second prosecution. In such circumstances, a

77. See Holleman, Mistrials and the Double Jeopardy Clause, 14 GA. L. REv. 45, 68-72 (1979).

78. 424 U.S. 600 (1976).

79. See United States v. Dinitz, 492 F.2d 53 (5th Cir. 1974).

80. Id. at 59.

81. See, e.g., Johnson v. Zerbst, 304 U.S. 458, 464 (1938) (waiver of right to counsel must be voluntarily and intelligently made). 
defendant's mistrial request has objectives not unlike the interests served by the Double Jeopardy clause-the avoidance of the anxiety, expense, and delay occasioned by multiple prosecutions. ${ }^{\mathbf{2 2}}$

The holding in Dinitz permits the defendant to apply the manifest necessity test for the district court. Mistrials requested or consented to by the defendant do not bar reprosecution because the ends of double jeopardy are served by the grant of a mistrial. Since society is unwilling to allow every prejudicial mishap to end permanently a prosecution, the defendant must make a choice between two unappealing alternatives. This forced election nevertheless allows the defendant to choose between the lesser of the two evils.

Are the ends of double jeopardy also served when the defendant is forced to choose a mistrial not only due to defense counsel misconduct but also because of prosecutorial overreaching? The Court confronted this question in Oregon $v$. Kennedy $y^{\mathbf{3}}$ and answered in the affirmative. In Kennedy, during cross-examination, the prosecutor called the defendant "a crook" in front of the jury. The defendant then moved for a mistrial and the court granted the request. When the state later sought to retry, the defendant pleaded former jeopardy. At the pre-trial hearing, the trial court found the prosecutor did not intend to cause a mistrial and therefore ruled that a second trial was proper. ${ }^{84}$

Following conviction, the Oregon Supreme Court sustained the double jeopardy challenge. It held that even though there was no improper intent on behalf of the prosecution, its actions constituted "overreaching." overreaching placed the defendant in an unsatisfactory position where his essentially forced request for a mistrial could not be considered a waiver of his double jeopardy rights. In this instance, the prosecutor's action created a true "Hobson's Choice - either to accept a necessarily prejudiced jury, or to move for a mistrial and face the process of being retried at a later time."s8

The Supreme Court disagreed. The Court reasoned that the chance of prosecutorial overreaching was an inevitable risk of a criminal trial. Since "[e]very act on the part of a rational prosecutor during a trial is designed to 'prejudice' the defendant" by trying to convince the fact-finder that the accused is guilty, "it will be a rare trial of any complexity in which some proffered evidence by the prosecutor or by the defendant's attorney will not be found objectionable by the trial court." 87 Because of its innocent character, overreaching properly requires the defendant to make the

82. Dinitz, 424 U.S. at 608.

83. 456 U.S. 667 (1982).

84. See State v. Kennedy, 49 Or. App. 415, 418, 619 P.2d 948, 949 (1980).

85. Id. at $417-18,619$ P. $2 \mathrm{~d}$ at 949 .

86. Id. at 418,619 P.2d at 950 .

87. Kennedy, 456 U.S. at $674-75$. 
choice between a mistrial or continuing with a tainted trial. The line is firmly drawn, though, at improper intent. If the prosecutor's actions are designed to cause a mistrial, then double jeopardy will bar a second trial. $^{88}$

The holdings in Dinitz and Kennedy lend full legitimacy to the forced election of the proposed solution. If factors such as prosecutorial overreaching are permitted to create a dilemma for the defendant, certainly the problem of the unreviewable judge should also count. As the Court noted in Kennedy, the complexity of evidentiary matters in many trials do create uncomfortable circumstances for the defendant. But social justice requires that these occasions should not act as a bar to retrying the defendant. Unpleasant as this process might be, the accused must bear the weight of the Government's need to preserve its right to appeal just as he must pay the price for the overreaching of a zealous prosecutor.

\section{Conclusion}

The problem of the unreviewable judge has often been ignored because it has been assumed that mid-trial evidentiary rulings could not be appealed under 18 U.S.C. $\S 3731$. But the solution proposed in this Note circumvents this dilemma by converting unappealable mid-trial suppression orders into appealable pre-trial ones. This solution is in no way designed to trump Congress' decision not to permit interlocutory appeals during trial. It is meant merely to supplement and protect the grant of appellate power to the prosecution regarding pre-trial evidentiary rulings.

The power to protect the Government's section 3731 rights is derived from courts' general authority with regard to mistrials. The lesson to be learned from mistrial cases such as Perez, Dinitz, and Kennedy is that the district judge has a duty to terminate a trial when unavoidable mishaps occur, and reprosecution is proper when the societal interest in retrial outweighs the interest of the defendant not to be unduly harassed. Mistrials based on hung juries, defense counsel misbehavior, and prosecutorial overreaching all fall outside the double jeopardy clause. There appear to be very sound reasons why the preservation of the Government's right to appeal should be added to this list.

88. Id. at 675-76. 